\title{
Théophile Gautier, Les Jeunes France et autres récits humoristiques
}

\section{Lise Sabourin}

\section{(2) OpenEdition}

10 Journals

\section{Édition électronique}

URL : http://journals.openedition.org/studifrancesi/542

DOI : 10.4000/studifrancesi.542

ISSN : 2421-5856

Éditeur

Rosenberg \& Sellier

\section{Édition imprimée}

Date de publication : 1 avril 2015

Pagination : 176

ISSN : 0039-2944

\section{Référence électronique}

Lise Sabourin, «Théophile Gautier, Les Jeunes France et autres récits humoristiques », Studi Francesi [En ligne], 175 (LIX | I) | 2015, mis en ligne le 01 avril 2015, consulté le 18 septembre 2020. URL : http:// journals.openedition.org/studifrancesi/542; DOI : https://doi.org/10.4000/studifrancesi.542

Ce document a été généré automatiquement le 18 septembre 2020.

\section{(c) $(1) \&$}

Studi Francesi è distribuita con Licenza Creative Commons Attribuzione - Non commerciale - Non opere derivate 4.0 Internazionale. 


\title{
Théophile Gautier, Les Jeunes France et autres récits humoristiques
}

\author{
Lise Sabourin
}

\section{RÉFÉRENCE}

THÉOPHILE GAUTIER, Les Jeunes France et autres récits humoristiques, présentation par Patrick BERTHIER, Paris, Garnier-Flammarion, 2013, pp. 338.

1 Après son anthologie de Gautier journaliste dans cette même collection, Patrick Berthier présente (pp. 7-23) et annote méticuleusement les six brefs «romans goguenards» qui constituent Les Jeunes France, publiés en 1833 chez Renduel, le grand éditeur de la décennie 1830-40, auxquels il adjoint six chroniques humoristiques parues en 1836.

2 Jeune écrivain de vingt-deux ans, qui n'est alors vraiment connu qu'au sein du Cénacle - ses premières Poésies parues en juillet 1830 étant passées inaperçues au milieu des événements et son Albertus de 1832 ayant plutôt choqué que séduit ses rares lecteurs -, Gautier s'y révèle à la fois tenant et observateur sarcastique du romantisme. Entre esprit bousingot et dandysme fashionable, il célèbre l'union de la poésie et de la peinture, tout en marquant le terme de la mode frénétique des années 25-30 en la pratiquant d'un ton ironique et libératoire.

Dès sa préface (pp. 29-45), il se présente comme désabusé en politique et adepte d'un art inutile, marque ses distances vis-à-vis de son lecteur, dont il moque plaisamment le désir de parcourir seulement préface et table des matières des livres prétendument connus.

Quant aux six «contes», ils semblent fort hétéroclites quoique mus par des thèmes communs - réflexions sur l'amour, la création, la dictature de la mode. Le dialogue d'ivrognes sur la vertu comparée de leurs maîtresses dans «Sous la table» (pp. 47-66) prépare le récit d'orgie à la Balzac ou Janin du «Bol de punch» (pp. 229-264), mais aussi le débat concernant la supériorité de l'amour domestique sur l'inaccessible passion dans «Celle-ci et celle-là» (pp. 129-218). À la vie fantastique d'un peintre rêveur frôlant 
la folie dans «Onuphrius» (pp. 67-104) répond la conversion romantique d'un bourgeois classique devenu excentrique avec «Daniel Jovard» (pp. 105-128) ou d'un artiste rêvant de vivre au Moyen-Âge pour «Élias Wildmanstadius» (pp. 219-228).

5 La dérision se poursuit dans la «Monographie du bourgeois parisien» (pp. 267-288) qui reprend certains traits de «Daniel Jovard», ainsi que dans les cinq chroniques du «Figaro»: «Du physique des acteurs» (pp. 289-292), «De l'à-propos dans la mort» (pp. 293-298), «Les littérateurs obèses» (pp. 299-306), «De la férocité de la critique» (pp. 307-312), «Prospectus philocome» (pp. 313-316).

6 Ce recueil permet de cerner vraiment l'esprit Jeune France, empreint d'humour et de panache, épris d'un idéal miné par la désillusion, qui trouve dans la satire les voies de la littérature tout en refusant de se laisser abuser par la puissance des mots. 